\title{
NEW WEIGHTED SIMPSON TYPE INEQUALITIES AND THEIR APPLICATIONS
}

\author{
J. PEČARIĆ AND KuEI-Lin TSENG
}

Abstract. In this paper, we establish some weighted Simpson type inequalities and give several applications for Euler's Beta mapping and special means.

Mathematics subject classification (2000): 26D15, $26 \mathrm{D} 10$.

Key words and phrases: Simpson's inequality, function of bounded variation, Euler's Beta function, special means.

\section{REFERENCES}

[1] T. M. Apostol, Mathematical Analysis, Second Edition, Addision-Wesley Publishing Company , 1975.

[2] D. CRUZ-URIBle AND C. J. NeugebAuER, Sharp error bounds for the trapezoidal rule and Simpson's rule, JIPAM. J. Inequal. Pure Appl. Math. 3 (2002), no. 4, Article 49, 22 pp.

[3] V. ČUlJaK, J. PeČARIĆ AND L. E. Persson, A note on Simpson's type numerical integration, Soochow J. Math. 29 (2003), no. 2, 191-200.

[4] S. S. Dragomir, On Simpson's quadrature formula and applications, Mathematica 43 (66) (2001), no. 2, 185-194 (2003).

[5] S. S. DRAGOMIR, On Simpson's quadrature formula for Lipschitzian mappings and applications, Soochow J. Math. 25 (1999), no. 2, 175-180.

[6] S. S. DRAGOMIR, On Simpson's quadrature formula for mappings of bounded variation and applications, Tamkang J. of Math. 30 (1999), no. 1, 53-58.

[7] S. S. Dragomir, R. P. Agarwal And P. CERone, On Simpson's inequality and applications, J. Inequal. Appl. 5 (2000), no. 6, 533-579.

[8] S. S. DRAGOMIR, On the Ostrowski's integral inequality for mappings with bounded variation and applications, Math. Inequal. Appl. no. 1, 59-66.

[9] J. PEČARIĆ AND S. VAROŠANEC, A note on Simpson's inequality for Lipschitzian functions, Soochow J. Math. 27 (2001), no. 1, 53-57.

[10] J. PEČARIĆ AND S. VAROŠANEC, Simpson's formula for functions whose derivatives belong to $L_{p}$ spaces, Appl. Math. Lett. 14 (2001), no. 2, 131-135.

[11] J. PEČARIĆ AND S. VAROŠANEC, A note on Simpson's inequality for functions of bounded variation, Tamkang J. of Math. 31 (2000), no. 3, 239-242.

[12] K. L. TSENG, G. S. YANG AND S. S. DRAGOMIR, On Weighted Simpson Type Inequalities and Applications, RGMIA Res. Rep. Coll., 7 (1) (2004), Art. 17.

[13] N. UjeVIĆ, New bounds for Simpson's inequality, Tamkang J. of Math. 33 (2002), no. 2, 129-138.

[14] G. S. YANG AND H. F. CHU, A note on Simpson's inequality for function of bounded variation, Tamsui Oxf. J. Math. Sci. 16 (2000), no. 2, 229-240. 